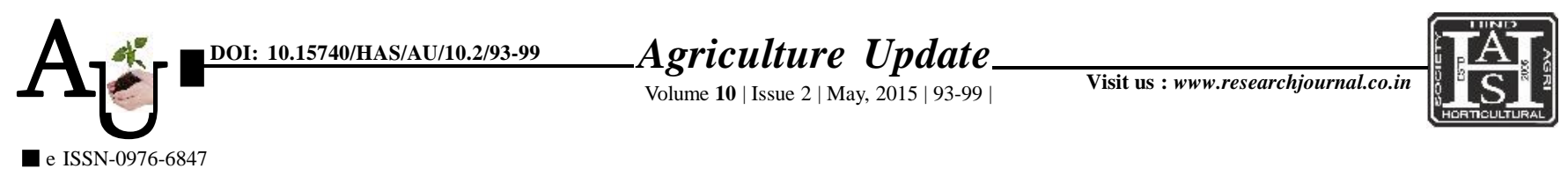

\title{
Research Article: Resource use efficiency in cultivation of major crops of Dharwad district
}

Article Chronicle:
Received :
15.11.2014;
Revised :
03.03.2015;
Accepted:
18.03.2015

KeY WoRds:

Resource use efficiency, Marginal value cost, Marginal fixed cost
Author for correspondence :

\section{LAXMI N. TIRLAPUR}

Department of

Agricultural Economics, College of Agriculture,

University of

Agricultural Sciences, DHARWAD (KARNATAKA) INDIA

Email: laxmint4424@

gmail.com

See end of the article for authors' affiliations

\section{LAXMI N. TIRLAPUR* AND S.M. MUNDINAMANI}

SUMMARY : Agriculture in India is one of the most important sectors of its economy. Though, the share of Indian agriculture in the GDP has been steadily declining over the years. Main reason for deceleration in agricultural growth is declining investment in agriculture research and development and irrigation, inefficiency of rural credit and extension. One more the most important factor is; inefficient use of resources is the reason for declined growth of agriculture sector. So the present study was under taken in Dharwad district to analyse the resource use efficiency of major crops. Major crops grown in the district such as chickpea, cotton, paddy, soybean, maize and chilli were selected for the study. Multistage random sampling was adopted for selection of sample respondents. Cobb-Douglas production technique was employed. Results of the study revealed that seed, fertilizers, PPC and machine labour were over utilized and human labour and bullock labour were underutilized by the chickpea farmers. Cobb-Douglas production function for cotton under rainfed condition revealed that seed, PPC, human labour and bullock labour were over utilized and FYM, fertilizer and machine labour were underutilized. During production of paddy seed, fertilizers, FYM, bullock labour and machine labour were over utilized and human labour and PPC were underutilized by the farmers. FYM and PPC were underutilized and seed, fertilizers, human labour, bullock labour and machine labour were underutilized by farmers in cultivation of soybean. Resource use efficiency under rainfed chilli production revealed that seed, PPC, bullock labour and machine labour were over utilized and FYM, fertilizer and human labour were under utilized by the farmers.

How to cite this article : Tirlapur, Laxmi N. and Mundinamani, S.M. (2015). Resource use efficiency in cultivation of major crops of Dharwad district. Agric. Update, 10(2): 93-99. 